American Journal of Environmental Sciences 5 (3): 352-363, 2009

ISSN 1553-345X

(C) 2009 Science Publications

\title{
Heterogeneous Modeling, Identification and Simulation of Activated Sludge Processes
}

\author{
${ }^{1}$ Ibrahim H. Mustafa, ${ }^{2}$ G. Ibrahim, ${ }^{1}$ Ali Elkamel and ${ }^{3}$ A.H. Elahwany \\ ${ }^{1}$ Department of Chemical Engineering, Waterloo University, Canada \\ ${ }^{2}$ Department of Basic Engineering Science, Faculty of Engineering, \\ Menofia University, Shebin El Kom, Egypt \\ ${ }^{3}$ Department of Chemical Engineering, Cairo University, Egypt
}

\begin{abstract}
Problem statement: The activated sludge system is a complex dynamic process and must account for a large number of reactions between large numbers of components. There is necessity for simulation models which describe the dynamic behavior of the activated sludge process. The application of the models in most treatment plants is limited due to lack of appropriate data acquisition and parameters identification studies. To realize this, an improvement of the operating strategies of Waste-Water Treatment Plants (WWTP) is required. The objectives of this study were to: (i) To build a process model considering mass transfer limitations and simulate an existing plant (Helwan WWTP) and validate the results using data from another existing plant with (Zenine WWTP). (ii) To adjust the model kinetic parameters of the biochemical reactions under the effect of mass transfer conditions to be prepared for simulation purposes. (iii) Study the effect of the operating conditions on the removal efficiency of both substrate and ammonia. Approach: A process model of the process was built considering mass transfer limitations and the three growth processes: Carbon oxidation, nitrification and denitrification. Helwan WWTP was used in order to extract the suitable stoichiometric and kinetic parameters to be used for the simulation. Helwan WWTP was used through the simulation results of the substrate (BOD) and ammonia. Egyptian Zenine WWTP was used for the testing and validation of the process model through predicting the response of substrate. Results: The average error of the removal efficiency in Helwan WWTP reached 3.3\% for the substrate and 12.5\% for the ammonia while the average error of the removal efficiency in Zenine WWTP of substrate reached $4.6 \%$. The effects of recycle ratio, flow rate and influent substrate concentrations on the removal efficiency of the aeration tank were studied. It was found that the removal efficiency of substrate and ammonia was increased by increasing the recycle ratio, influent substrate concentrations and also increased by decreasing influent flow rates. It was found also that the sludge age increased by increasing the recycle ratio and decreased by decreasing the influent flow rates. Conclusion: The heterogeneous process model was able to describe the characteristics and reflects the real phenomena existing in activated sludge processes.
\end{abstract}

Key words: Activated sludge, mass transfer, carbon oxidation, nitrification, gentrification, removal, efficiency, recycle ratio, flow rate, aeration tank, sludge age

\section{INTRODUCTION}

Activated sludge is a complex dynamic process and simulation of such systems must necessarily account for a large number of reactions between a large numbers of components. There is a need for simulation models that describe the dynamic behavior of such important process process. Simulation models of the activated sludge process are believed to be useful tools for research, process, optimization and troubleshooting at full-scale treatment plants, in addition to serving a teaching and design assistance tools. However, the application of the models in most treatment plants is limited due to a lack of advanced input parameters values required by the models. To improve the operating efficiencies of current wastewater treatment plants, both municipal and industrial engineers have looked at automatic process control. This work is an extension of our previous work Ibrahim Mustafa et al. ${ }^{[1]}$.

Figure 1 shows a schematic diagram of the activated sludge process where aeration basins (reactors) are typically open tanks containing equipment to provide aeration and to provide sufficient mixing energy to keep the MLSS in suspension.

Corresponding Author: Ibrahim H. Mustafa, Department of Chemical Engineering, Waterloo University, Canada 
Am. J. Environ. Sci., 5 (3): 352-363, 2009

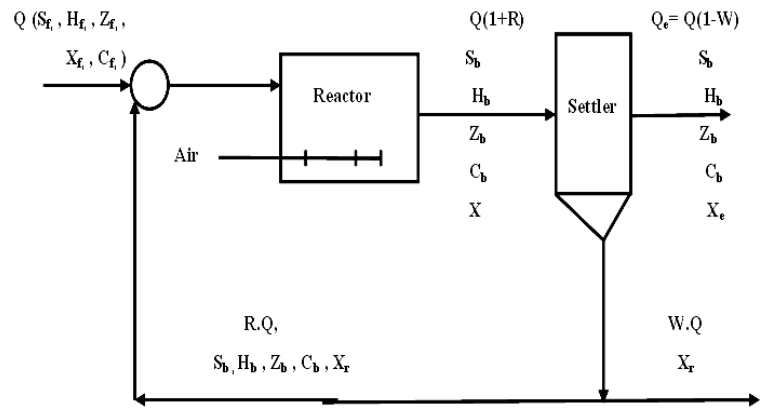

Fig. 1: Schematic diagram of the activated sludge process

The depth is mainly determined by energy transfer/mixing characteristics and usually ranges from $3-7.5 \mathrm{~m}^{[2]}$. A single piece of equipment such as diffused air, mechanical surface aerator, or jet aerator is used in many cases to provide aeration and keep the solids in suspension. Auxiliary mechanical mixers are used when the aeration does not provide sufficient mixing energy.

The secondary clarifier performs two functions in the activated sludge process. The first function, clarification, is the separation of MLSS from the treated wastewater to produce a clarified effluent that meets the effluent suspended solids goal. The other is the thickening of sludge to be recycled to the bioreactor. Since both functions are affected by clarifier depth, the design depth must be selected to provide an adequate volume for both functions ${ }^{[1,3]}$. For instance, the volume must be sufficient to store the solids during periods of high flow.

The objectives of this study are:

- To build a process model considering mass transfer limitations and simulates an Egyptian plant: Helwan wastewater treatment plant that exists in the south of Cairo and has a capacity of $350,000 \mathrm{~m}^{3}$ day $^{-1}$ and average removal efficiency of $85 \%$ for substrate and $62 \%$ for ammonia. To be more sure of the simulation results, the model validation was performed for Zenine wastewater treatment plant that exists in the west of Cairo and has a capacity of $330000 \mathrm{~m}^{3}$ day $^{-1}$ and average removal efficiency of $87.6 \%$ for substrate

- To adjust the model kinetic parameters of the biochemical reactions of the three growth processes: Carbon oxidation, nitrification and denitrification under the effect of mass transfer conditions to be prepared for the simulation purpose

- To Study the effect of the operating conditions such as flow rate, recycle ratio and feed substrate concentrations on the removal efficiency of both substrate and ammonia
Activated sludge process model development: The key to successful modeling of the activated sludge process is the appropriate assumptions to achieve a compromise between complexity and utility. The present study is concerned with the general derivation of a dynamic model of the activated sludge process in the bioreactor. The bioreactor (aeration basin) model describes the removal of organic matter, nitrification and denitrification. The bioreactor model is based on the previous biofloc model which depends on activated sludge model number one, ASM1, by considering both the mass transfer limitations and biochemical process reactions ${ }^{[3]}$. The simulation model considers the four main components: BOD readily biodegradable Substrate (S), ammonia $(\mathrm{H})$, Nitrate $(\mathrm{Z})$ and oxygen (C). The assumptions in the biofloc model are considered here in the process model in addition to the following assumptions:

- The power input used in the bioreactor is assumed to be $80 \%$ of the maximum value to realize complete mixing in the reactor

- The effluent biomass concentration is be neglected,

- The consumption of substrate, ammonia and oxygen in the settler is neglected

- Constant average volumetric flow rate of the influent is considered

- Constant average recycle ratio and wastage ratio is considered

- The details of the process model developed appear in the schematic diagram shown in Fig. 1

Derivation of the process model: The derivation of mass balances on the settler and the bioreactor is considered. The derivation of mass balance equations of substrate is considered by applying mass balance on the settler in order to get the biomass concentration exiting which is recycled to the bioreactor; then mass balance equations of the bioreactor will be derived.

Applying a component mass balance on biomass for the settler gives:

$\mathrm{Q}(1+\mathrm{R}) \mathrm{X}=\mathrm{Q}(\mathrm{R}+\mathrm{W}) \mathrm{X}_{\mathrm{r}}+\mathrm{Q}_{\mathrm{e}} \mathrm{X}_{\mathrm{e}}$

Hence, the effluent biomass concentration is neglected, $\mathrm{X}_{\mathrm{e}}=0.0$.

Then:

$X_{r}=\left(\frac{1+R}{R+W}\right) X$

By performing mass balance on the reactor, the following equations are obtained: 
Mass balance on substrate (S): If substrate consumption in the settling tank is neglected and there is substantial decrease in the water content of the settled sludge related to that measured so that:

$$
\mathrm{S}_{\text {before settler }}=\mathrm{S}_{\text {after settler }}
$$

Applying a component mass balance on substrate for the bioreactor gives:

Substrate Inflow $=$ Outflow + Net growth + Accumulation:

$$
\begin{aligned}
& \mathrm{QS}_{\mathrm{f}}+\mathrm{RQ}_{\mathrm{b}}=\mathrm{Q}(1+\mathrm{R}) \mathrm{S}_{\mathrm{b}}+\mathrm{K}_{\mathrm{gs}} \mathrm{A}_{\mathrm{tf}}\left(\mathrm{S}_{\mathrm{b}}-\mathrm{S}_{\mathrm{S}}\right)+\mathrm{V} \frac{\mathrm{dS} \mathrm{S}_{\mathrm{b}}}{\mathrm{dt}} \\
& \frac{\mathrm{V}}{\mathrm{Q}} \frac{\mathrm{dS}}{\mathrm{dt}}=\mathrm{S}_{\mathrm{f}}-\mathrm{S}_{\mathrm{b}}-\frac{\mathrm{K}_{\mathrm{gs}} \mathrm{A}_{\mathrm{tf}}}{\mathrm{Q}}\left(\mathrm{S}_{\mathrm{b}}-\mathrm{S}_{\mathrm{s}}\right)
\end{aligned}
$$

Mass balance on ammonia (H): Ammonia nitrogen can be removed from wastewater by volatilization of gaseous ammonia. Gas stripping is most effective when contaminated wastewater is exposed to free air. Hence, this process is considered by adding a factor of ammonia stripping $\left(G_{f}\right)$ to the first order differential equation of ammonia.

Applying a component mass balance on ammonia for the bioreactor gives:

$\mathrm{NH}_{3}$ accumulated $=\mathrm{NH}_{3} \quad$ Inflow $-\mathrm{NH}_{3} \quad$ Outflow $-\mathrm{NH}_{3}$ Volatilized by air stripping:

$\frac{\mathrm{V}}{\mathrm{Q}} \frac{\mathrm{dH}_{\mathrm{b}}}{\mathrm{dt}}=\mathrm{H}_{\mathrm{f}}-\mathrm{H}_{\mathrm{b}}-\mathrm{G}_{\mathrm{f}} \frac{\mathrm{K}_{\mathrm{gh}} \mathrm{A}_{\mathrm{tf}}}{\mathrm{Q}}\left(\mathrm{H}_{\mathrm{b}}-\mathrm{H}_{\mathrm{s}}\right)$

Mass balance on nitrate $(\mathbf{Z})$ : Applying a component mass balance on nitrate for the bioreactor gives:

Nitrate Inflow $=$ Nitrate Outflow + Net growth of Nitrate + Nitrate Accumulation

$\frac{\mathrm{V}}{\mathrm{Q}} \frac{\mathrm{dZ}}{\mathrm{dt}}=\mathrm{Z}_{\mathrm{f}}-\mathrm{Z}_{\mathrm{b}}-\frac{\mathrm{K}_{\mathrm{gz}} \mathrm{A}_{\mathrm{tf}}}{\mathrm{Q}}\left(\mathrm{Z}_{\mathrm{b}}-\mathrm{Z}_{\mathrm{s}}\right)$

Mass balance on oxygen (C): Applying a component mass balance on oxygen for the bioreactor gives:

$$
\begin{aligned}
& \text { Oxygen Inflow }=\text { Oxygen Outflow }+ \text { Net growth of } \\
& \text { Oxygen + Oxygen Accumulation }
\end{aligned}
$$$$
\frac{\mathrm{V}}{\mathrm{Q}} \frac{\mathrm{dC}_{\mathrm{b}}}{\mathrm{dt}}=\mathrm{C}_{\mathrm{f}}+\frac{\mathrm{V}}{\mathrm{Q}} \mathrm{K}_{1} \mathrm{a}\left(\mathrm{C}^{*}-\mathrm{C}_{\mathrm{b}}\right)-\mathrm{C}_{\mathrm{b}}-\frac{\mathrm{K}_{\mathrm{gc}} \mathrm{A}_{\mathrm{tf}}}{\mathrm{Q}}\left(\mathrm{C}_{\mathrm{b}}-\mathrm{C}_{\mathrm{s}}\right)
$$

Mass balance on biomass (X): Applying a component mass balance on biomass for the bioreactor gives:
Input $=$ Output + Rate of Reaction + Accumulation

Hence:

$$
\mathrm{QX}_{\mathrm{f}}+\mathrm{RQ}\left(\frac{1+\mathrm{R}}{\mathrm{R}+\mathrm{W}}\right) \mathrm{X}=\mathrm{Q}(1+\mathrm{R}) \mathrm{X}-\mathrm{r}_{\mathrm{x}} \mathrm{V}+\mathrm{V} \frac{\mathrm{dX}}{\mathrm{dt}}
$$

Hence:

$$
\frac{\mathrm{V}}{\mathrm{Q}} \frac{\mathrm{dX}}{\mathrm{dt}}=\mathrm{X}_{\mathrm{f}}+\frac{\mathrm{V}}{\mathrm{Q}} \mathrm{r}_{\mathrm{x}}+\frac{\mathrm{W}(1+\mathrm{R})}{(\mathrm{W}+\mathrm{R})} \mathrm{X}
$$

From task group $^{[4]}$ the rate of reaction of heterotrophic and autotrophic biomass can be obtained as follows:

$$
\begin{aligned}
\mathrm{r}_{\mathrm{x}}= & \mu_{\mathrm{H}}\left(\frac{\mathrm{S}_{\mathrm{b}}}{\mathrm{K}_{\mathrm{s}}+\mathrm{S}_{\mathrm{b}}}\right)\left(\frac{\mathrm{C}_{\mathrm{b}}}{\mathrm{K}_{\mathrm{oH}}+\mathrm{C}_{\mathrm{b}}}\right) \\
& +\eta_{\mathrm{g}} \mu_{\mathrm{H}}\left(\frac{\mathrm{S}_{\mathrm{b}}}{\mathrm{K}_{\mathrm{s}}+\mathrm{S}_{\mathrm{b}}}\right)\left(\frac{\mathrm{K}_{\mathrm{c}}}{\mathrm{K}_{\mathrm{c}}+\mathrm{C}_{\mathrm{b}}}\right)\left(\frac{\mathrm{Z}_{\mathrm{b}}}{\mathrm{K}_{\mathrm{z}}+\mathrm{Z}_{\mathrm{b}}}\right) \\
& +\mu_{\mathrm{A}}\left(\frac{\mathrm{H}_{\mathrm{b}}}{\mathrm{K}_{\mathrm{h}}+\mathrm{H}_{\mathrm{b}}}\right)\left(\frac{\mathrm{C}_{\mathrm{b}}}{\mathrm{K}_{\mathrm{cA}}+\mathrm{C}_{\mathrm{b}}}\right)-\mathrm{b}_{\mathrm{H}}-\mathrm{b}_{\mathrm{A}}
\end{aligned}
$$

These dynamic model equations are first order differential equations and can be solved by the following technique.

Solution technique: The initial value problems given by the above equations are solved by Gear's method for multiple ordinary differential equations (1985). A computer program was written for this purpose. A large number of data points have been taken to improve the accuracy of the results when the parameters in the model were being estimated.

Results and Discussion: Selecting suitable kinetic and stoichiometric parameters is considered by using Helwan WWTP data. It covers also the model testing by carrying out the simulation on Helwan WWTP on substrate BOD and ammonia concentrations. Zenine WWTP was used for the testing and validation of the process model through predicting the response of substrate only as will be shown.

Parameters Evaluation: Shieh and Mulcahy ${ }^{[5]}$ used an experimental procedure for the determination of intrinsic kinetic coefficients. The experimental apparatus (rotating disk biofilm reactor) provides a relatively simple, yet rigorous means for examination of 
Am. J. Environ. Sci., 5 (3): 352-363, 2009

both intrinsic and mass transfer limited kinetics. It allows for direct measurement of intrinsic kinetic coefficients and biological parameters relevant to a given reaction. The intrinsic kinetic coefficient of biological denitrification measured in their study is $\mathrm{K}_{\mathrm{z}}=2.875 \mathrm{mg} \mathrm{NO} 3-\mathrm{N}_{2}$ day $^{-1}$ and nitrate-nitrogen effective diffusivity is De $=0.815 \times 10^{-5} \mathrm{~cm}^{2} \mathrm{sec}^{-1}$.

Alison et al. ${ }^{[6]}$ measured the maximum specific growth rate $\mu_{\max }$ and the half saturation coefficient $\left(\mathrm{K}_{\mathrm{s}}\right)$. A simple respirometric technique was used where different volumes of concentrated wastewater were contacted with biomass and the response measured as a change in oxygen uptake rate $\triangle \mathrm{OUR}$. The $\triangle \mathrm{OUR}$ was then related to the growth rate and a series of substrate concentration/growth rate relationships determined from which $\mu_{\max }$ and $\mathrm{K}_{\mathrm{s}}$ were calculated. Typical $\mu_{\max }$ and $K_{\mathrm{s}}$ values published for municipal sewage are in the range $\mu_{\max }=1-5$ day $^{-1}$, with typical values of 2.5 day $^{-1[7]}$. The range $\mathrm{Ks}=6-19 \mathrm{mg} \mathrm{L}^{-1}$, with a typical value of $12 \mathrm{mg} \mathrm{L}^{-1}$.

Here, the component mass balance equations on the substrate, ammonia, nitrate, oxygen, autotrophic and heterotrophic biomass derived above are considered in order to extract the best values of parameters to simulate Helwan WWT plant performance. Hence, different measurements were taken from Helwan wastewater treatment plant data and an appropriate sequential quadratic programming scheme was performed to obtain the optimum set of parameters at which the theoretical predictions (the output of the simulation model program) are very close to the measured results (the output from Helwan WWTP). The data shown in Table 1 are used as input for the model program. The suitable parameters in turn will be used during the validation stage when we consider simulation of Zenine WWTP. Table 1 shows the average measured values of process parameters for Helwan WWTP.

Using the kinetic and stoichiometric parameters in the literature in ASMI we can now perform a complete simulation. However, in order to get acceptable agreements between the real and theoretical concentrations, numerical estimation of some parameters is necessary. To simplify this procedure, the relations between the effluent concentrations of the components and the kinetic and stoichiometric coefficients used in the model should be known. It was found that the effluent concentration of substrate, ammonia are directly proportional to the values of some parameters such as saturation coefficients such as Ks, $\mathrm{K}_{\mathrm{A}}, \mathrm{K}_{\mathrm{CA}}, \ldots$ and yield coefficients such as $\mathrm{Y}_{\mathrm{H}}$ and $\mathrm{Y}_{\mathrm{A}}$.
Table 1: Average values of process parameters for Helwan WWTP.

\begin{tabular}{lr}
\hline Parameter & Value \\
\hline $\mathrm{Q}_{\mathrm{o}}\left(\mathrm{m}^{3}\right.$ day $\left.^{-1}\right)$ (inlet flow) & 43.750 \\
$\mathrm{R}(\%)$ & 60.000 \\
$\mathrm{~W}(\%)$ & 3.500 \\
$\mathrm{~S}_{\mathrm{f}}\left(\mathrm{mg} \mathrm{L}^{-1}\right)$ (BOD) & 83.000 \\
$\mathrm{H}_{\mathrm{f}}\left(\mathrm{mg} \mathrm{L}^{-1}\right)$ (ammonia) & 1.030 \\
$\mathrm{Z}_{\mathrm{f}}\left(\mathrm{mg} \mathrm{L}^{-1}\right)$ (nitrate) & 11.000 \\
$\mathrm{SVI}\left(\mathrm{mL} \mathrm{g}^{-1}\right)$ & 57.000 \\
$(\mathrm{P} / \mathrm{V})\left(\mathrm{W} \mathrm{m}^{-3}\right)$ & 109.700 \\
$\mathrm{~V}\left(\mathrm{~m}^{3}\right)($ reactor volume) & 3000.000 \\
$\mathrm{X}_{\mathrm{f}}\left(\mathrm{mg} \mathrm{L}^{-1}\right)$ (biomass) & 50.000 \\
\hline
\end{tabular}

Table 2: The parameter values extracted from the floc model

\begin{tabular}{|c|c|c|}
\hline Symbol & Value & Explanation \\
\hline$\overline{\mathrm{Y}_{\mathrm{A}}}$ & 0.55 & Yield for autotrophic biomass \\
\hline $\mathrm{Y}_{\mathrm{H}}$ & 0.7 & Yield for heterotrophic biomass \\
\hline$\mu_{\mathrm{A}}$ & 0.42 day $^{-1}$ & $\begin{array}{l}\text { Maximum specific growth rate } \\
\text { for autotrophic biomass }\end{array}$ \\
\hline$\mu_{\mathrm{H}}$ & $4.35 \mathrm{day}^{-1}$ & $\begin{array}{l}\text { Maximum specific growth } \\
\text { rate for heterotrophic biomass }\end{array}$ \\
\hline $\mathrm{K}_{\mathrm{s}}$ & $220 \mathrm{mg} \mathrm{L}^{-1}$ & $\begin{array}{l}\text { half saturation coefficient for } \\
\text { heterotrophic biomass }\end{array}$ \\
\hline $\mathrm{K}_{\mathrm{cl}}$ & $0.05 \mathrm{mg} \mathrm{O}_{2} \mathrm{~L}^{-1}$ & $\begin{array}{l}\text { Oxygen half saturation coefficient } \\
\text { for heterotrophic biomass }\end{array}$ \\
\hline $\mathrm{K}_{\mathrm{z}}$ & $0.15 \mathrm{mg} \mathrm{NO}_{3}-\mathrm{N} \mathrm{L}^{-1}$ & $\begin{array}{l}\text { Nitrate half saturation coefficient } \\
\text { denitrifying heterotrophic biomass }\end{array}$ \\
\hline $\mathrm{K}_{\mathrm{A}}$ & 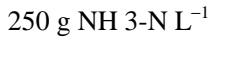 & $\begin{array}{l}\text { Ammonium half saturation } \\
\text { coefficient for autotrophic biomass }\end{array}$ \\
\hline $\mathrm{K}_{\mathrm{c} 2}$ & $2 \mathrm{mg} \mathrm{O}_{2} \mathrm{~L}^{-1}$ & $\begin{array}{l}\text { Oxygen half saturation coefficient } \\
\text { for autotrophic biomass }\end{array}$ \\
\hline $\mathrm{b}_{\mathrm{A}}$ & $0.08 \mathrm{day}^{-1}$ & $\begin{array}{l}\text { Decay rate coefficient for } \\
\text { autotrophic biomass }\end{array}$ \\
\hline$b_{H}$ & 0.62 day $^{-1}$ & $\begin{array}{l}\text { Decay rate coefficient for } \\
\text { heterotrophic biomass }\end{array}$ \\
\hline$\eta_{\mathrm{g}}$ & 0.8 & $\begin{array}{l}\text { Correction factor for } \mu_{\mathrm{H}} \text { under } \\
\text { anoxic conditions }\end{array}$ \\
\hline $\mathrm{C}^{*}$ & $9.8 \mathrm{mg} \mathrm{L}^{-1}$ & Saturated oxygen concentration \\
\hline
\end{tabular}

Also, it was found that they are inversely proportional to growth rates such as $\mu_{\mathrm{H}}, \mu_{\mathrm{A}}$. These relations are very useful to reach the best values of kinetic and soichiometric coefficients that make the theoretical results comparatively much closer to those of the real systems.

The values given in Table 2 are considered typical for neutral $\mathrm{pH}$ and domestic wastewater. The selected values of the kinetic and stoichiometric coefficients shown in Table 2 represent a set of values that result in a good fit of the experimental data and the model predictions.

The following are some observations on the values shown in Table 2:

- $\quad$ Some parameters such as C (saturated) $=9.8 \mathrm{mg} \mathrm{L}^{-1}$, density, diffusivities, viscosity, are adopted from the literature

- Diffusivity inside flocs is assumed to be $80 \%$ of that in pure water 
- Some parameter values such as $\mu_{\mathrm{H}}, \mu_{\mathrm{A}}$ are within the same range of activated sludge model number one, ASM1 ${ }^{[4]}$

- Some parameters values such as $\mathrm{K}_{\mathrm{S}}, \mathrm{K}_{\mathrm{A}}, \mathrm{K}_{\mathrm{CH}}$...are out of the range of ASMI by Henze et al. ${ }^{[4]}$ considering the mass transfer limitations

- The study of parametric sensitivity of the model has shown that the influence of the parameters of $\mathrm{Y}_{\mathrm{A}}$ and $\mathrm{K}_{\mathrm{A}}$ is not large on the effluent concentration of ammonia. It can be explained that the fraction of the autotrophs that oxidize ammonia in the aerobic growth process to the heterotrophs is very small, so the effluent ammonia is more sensitive to $\mu_{\mathrm{H}}$ and $b_{\mathrm{H}}$ than $\mu_{\mathrm{A}}$ and $\mathrm{b}_{\mathrm{A}}$ for the same reason

- The assumed values for ammonia stripping factor $\mathrm{G}_{\mathrm{F}}=0.075$ is attributed to multaneously losing of ammonia loss due to practical conditions such as agitation, temperature, exposed surface area plus non-adding any chemicals such as lime inside the aeration basin

- The value for $\mu_{\mathrm{g}}$ agrees with the literature

- The average experimental value for the ratio of active biomass in flocs is nearly 0.8 . This makes the effluent biomass falls in the range $2.2-3 \mathrm{~g} \mathrm{~L}^{-1}$, this is in agreement with literature ${ }^{[8]}$.

Model testing: Zhang et al. ${ }^{[9]}$ performed some trials for coke wastewater treatment plant by fixed biofilm system for $\mathrm{COD}$ and $\mathrm{NH}_{3}-\mathrm{N}$ removal. The experimental results showed that this system was efficient and stable in $\mathrm{COD}$ and $\mathrm{NH}_{3}-\mathrm{N}_{2}$ reductions. The effluent $\mathrm{COD}$ and $\mathrm{NH}_{3}-\mathrm{N}_{2}$ were 114 and $3.1 \mathrm{mg} \mathrm{L} \mathrm{L}^{-1}$ with removal efficiency of 92.4 and $98.8 \%$ respectively.

In order to test the accuracy of the values obtained for the parameters, numerical runs of the model have been carried out for the simulation model that uses the parameters obtained for the model and the constants which define the characteristics of the system.

The model proposed in this study was tested in a similar manner. Helwan WWTP data, which were used for the extraction of kinetic and stoichiometric coefficient as shown in Table 2, are used in order to test the model. The theoretical results (or the model predictions) in terms of the effluent concentrations were compared against the field results of Helwan WasteWater Treatment Plant (WWTP).

\section{Operating data for Helwan WWTP aeration basin:}

The aeration basin volume
Cross sectional area
Volumetric flow rate
Percentage of average
Recycle ratio

$$
\begin{aligned}
& =3,200 \mathrm{~m}^{3} \\
& =806.88 \mathrm{~m}^{2} \\
& =43,750 \mathrm{~m}^{3} \text { day }^{-1} \\
& =30-120 \% \text { of the feed }
\end{aligned}
$$

Percentage of average

wastage ratio

The power input in $\left(\mathrm{W} \mathrm{m}^{-3}\right)$ :

For the aeration basin $\quad=200 \mathrm{~kW}$ on the basis of 80

Percentage of the available maximum power input

The technique of aeration: The technique of aeration used in the plant is mechanical surface aeration where the wastewater is agitated at the surface to promote the transfer of oxygen to the water from the atmosphere above the liquid. The surface aerators also throw water into the air to increase contact area. The agitator type used is in a cone turbine with 16 blades

Available volumetric flow rate of air = $1246.36 \mathrm{~m}^{3} \mathrm{~h}^{-1}$. Evaluation of $\mathrm{K}_{\mathrm{la}}$ according to the following correlation, $\mathrm{K}_{\mathrm{la}}$ is a function of power input $\mathrm{m}^{-3}$ of liquid volume $(\mathrm{P} / \mathrm{V})$ in the aeration basin:

$\mathrm{K}_{\mathrm{la}}=\frac{\mathrm{K}_{\mathrm{lamax}}(\mathrm{P} / \mathrm{V})}{(\mathrm{P} / \mathrm{V})+\mathrm{k}}$

Where:

$\begin{array}{ll}\mathrm{V}(\text { occupied reactor volume }) & =1822.91 \mathrm{~m}^{3} \\ \mathrm{P} & =200 \mathrm{~kW} \\ \text { Hence: } & =109.71 \mathrm{~W} \mathrm{~m}^{-3} \\ \mathrm{P} / \mathrm{V} & =500 \mathrm{day}^{-1} \\ \text { By fitting: } & =450 \\ \mathrm{~K}_{\mathrm{la} \max } & \\ \mathrm{K} & =98.01 \mathrm{day}^{-1} \\ \text { Hence: } & \end{array}$

Simulation results for Helwan WWTP: It is important to note that the effluent BOD and ammonia field data can only serve as a rough guide for evaluating the model behavior because they are very noisy ${ }^{[10]}$.

Considering the previous operating data for the northern aeration basin for Helwan WWTP in the simulation model for readily biodegradable substrate BOD (S) and ammonia (H), the results shown in Table 3 and 4 were obtained.

Percentage of average removal efficiency relative error:

$=\left|\frac{\mathrm{S}_{\text {out real }}-\mathrm{S}_{\text {out theo }}}{\mathrm{S}_{\mathrm{f}}}\right| * 100$

The average removal error between the theoretical and real values of ammonia $(\mathrm{H})$ comes from the air stripping operation where the assumed value of the air stripping operation where the assumed value of the air stripping factor may not be accurate enough to express the real amount which was lost when exposed to free air. 
Am. J. Environ. Sci., 5 (3): 352-363, 2009

Table 3: Simulation results for Helwan WWTP, in Feb. 2002

\begin{tabular}{|c|c|c|c|c|c|c|c|c|c|}
\hline \multirow[b]{2}{*}{ Date } & \multicolumn{3}{|l|}{ Feed } & \multicolumn{2}{|l|}{$\mathrm{S}_{\text {out }}$} & \multicolumn{2}{|l|}{$\mathrm{H}_{\text {out }}$} & \multicolumn{2}{|c|}{$\begin{array}{l}\text { Percentage of average } \\
\text { removal error }\end{array}$} \\
\hline & $\mathrm{S}_{\mathrm{f}}\left(\mathrm{mg} \mathrm{L}^{-1}\right)$ & $\mathrm{H}_{\mathrm{f}}\left(\mathrm{mg} \mathrm{L}^{-1}\right)$ & $\operatorname{SVI}\left(\mathrm{mL} \mathrm{g}^{-1}\right)$ & Real & Theo. & Real & Theo. & $\mathrm{S}(\%)$ & $\mathrm{H}(\%)$ \\
\hline $3 / 2 / 96$ & 83 & 11.0 & 57 & 12 & 12.075 & 5.3 & 5.593 & 0.010 & 2.67 \\
\hline $10 / 2$ & 83 & 12.5 & 56 & 14 & 12.076 & 3.0 & 6.300 & 2.320 & 26.40 \\
\hline $13 / 2$ & 90 & 13.1 & 56 & 20 & 12.700 & 11.0 & 6.670 & 8.110 & 33.10 \\
\hline $16 / 2$ & 88 & 12.3 & 57 & 14 & 12.526 & 4.5 & 6.250 & 1.700 & 14.23 \\
\hline $21 / 2$ & 69 & 12.0 & 47 & 17 & 11.000 & 5.3 & 6.800 & 8.750 & 12.50 \\
\hline $26 / 2$ & 69 & 11.3 & 53 & 10 & 10.680 & 3.0 & 5.800 & 12.000 & 4.78 \\
\hline Averag & & & & & & & & 3.650 & 18.95 \\
\hline
\end{tabular}

Table 4: Simulation results for Helwan WWTP, in March 2002

\begin{tabular}{|c|c|c|c|c|c|c|c|c|c|}
\hline \multirow[b]{2}{*}{ Date } & \multicolumn{3}{|l|}{ Feed } & \multicolumn{2}{|l|}{$\mathrm{S}_{\text {out }}$} & \multicolumn{2}{|l|}{$\mathrm{H}_{\text {out }}$} & \multicolumn{2}{|c|}{$\begin{array}{l}\text { Percentage of average } \\
\text { removal error }\end{array}$} \\
\hline & $\mathrm{S}_{\mathrm{f}}\left(\mathrm{mg} \mathrm{L}^{-1}\right)$ & $\mathrm{H}_{\mathrm{f}}\left(\mathrm{mg} \mathrm{L}^{-1}\right)$ & $\operatorname{SVI}\left(\mathrm{mL} \mathrm{g}^{-1}\right)$ & Real & Theo. & Real & Theo. & $\mathrm{S}(\%)$ & $\mathrm{H}(\%)$ \\
\hline$\overline{2 / 3}$ & 221 & 18.8 & 57 & 31 & 20.460 & 10.6 & 11.15 & 4.770 & 4.700 \\
\hline $6 / 3$ & 427 & 20.6 & 56 & 39 & 47.000 & 11.9 & 13.47 & 2.820 & 7.620 \\
\hline $11 / 3$ & 266 & 20.3 & 56 & 34 & 41.900 & 15.6 & 13.23 & 2.970 & 11.400 \\
\hline $23 / 3$ & 280 & 15.4 & 57 & 48 & 54.330 & 10.2 & 10.10 & 2.300 & 0.650 \\
\hline $30 / 3$ & 248 & 23.3 & 47 & 28 & 23.348 & 12.5 & 13.90 & 2.000 & 6.000 \\
\hline Average error & & & & & & & & 2.972 & 6.074 \\
\hline
\end{tabular}

In fact, for a real plant the stripping factor is not constant but depends on the practical situations. The average removal error between the theoretical and real error is as shown in the range of (6-19\%).

Model validation: Helwan WWTP is used for the manipulation of kinetic parameters and stoichiometric coefficient as shown in Table 2 and used also for testing the model. However, Zenine WWTP is used for the validation of the model using the same kinetic and stoichiometric coefficients. Zenine WWTP exists in the west of Cairo. It treats wastewater in a capacity of $330,000 \mathrm{~m}^{3} \mathrm{day}^{-1}$. It consists of 3 modules; each one contains 22 aeration basins. They have the same volume and the same method of aeration and different conditions. It is noted that the volumes of the aeration basins in Zenine WWTP are smaller than those of Helwan WWTP but their numbers in Zenine WWTP are greater.

\section{Operating data for Zenine WWTP aeration basin:}

- The aeration basin volume $=537 \mathrm{~m}^{3}$

- Cross sectional area $=50 \mathrm{~m}^{2}$

- Volumetric flow rate $=5,000 \mathrm{~m}^{3}$ day $^{-1}$

- Percentage of average recycle ratio $=90 \%$ of the feed

- $\quad$ Percentage of Average wastage ratio $=0.5-5.0 \%$ of the feed

- The power input in $\left(\mathrm{W} \mathrm{m}^{-3}\right)$ : For the aeration basin $=40.33 \mathrm{~kW}$ on the basis of $75 \%$ of the available maximum power input

- The technique of aeration: The technique of the aeration method used in the plant is the diffused air technique, where the air is introduced below the surface through diffusers or nozzles, the rise has been found that $\mathrm{K}_{\mathrm{la} \max }=500 \mathrm{day}^{-1}, \mathrm{~K}=450$, hence, $\mathrm{K}_{\mathrm{la}}=150.41 \mathrm{day}^{-1}$

Simulation results for Zenine WWTP: The previous operating data of aeration basin in module 3 for Zenine WWTP and stoichiometric and kinetic parameters shown in Table 2 are used in order to validate the simulation model. Readily biodegradable substrate BOD (S) only is used for the purpose of validation because of unavailable data for the other components such as ammonia. The simulation model was applied for a period 12 months for BOD. Table 5-10 show some simulation results for Zenine WWTP. Velocity of the bubbles creates a circulating mixing pattern in the liquid. The available volumetric flow rate of air $=1227.3 \mathrm{~m}^{3} \mathrm{~h}^{-1}$. Evaluation of $\mathrm{K}_{\mathrm{la}}$ was done in the same way as above, using the same correlation 6 Where $\mathrm{V}$ (occupied reactor volume $)=208.33 \mathrm{~m}^{3}$ and $\mathrm{P}=40.33 \mathrm{~kW}$, hence, $\mathrm{P} / \mathrm{V}=193.6 \mathrm{~W} \mathrm{~m}^{-1}$, by fitting it from Table 5-10 it can be showed that the \% average removal error of the removal efficiency of substrate (BOD) between the real and theoretical results of Zenine WWTP equals $4.634 \%$. The results show that the theoretical and the real values of substrate (BOD) are in good agreement. These results give a good indication that the model is able to predict the output of the aeration tank in a wastewater treatment plant.

Parametric study of activated sludge process: The parametric study is expected to play an important role in the evaluation of the performance of the aeration basin in activated sludge plants. Hence, it is very important to study the performance of the aeration basin. 
Am. J. Environ. Sci., 5 (3): 352-363, 2009

Table 5: Simulation results for Zenine WWTP in Jan. 2001

\begin{tabular}{|c|c|c|c|c|c|}
\hline \multirow[b]{2}{*}{ Date } & \multirow[b]{2}{*}{$\mathrm{S}_{\mathrm{f}}$} & \multirow[b]{2}{*}{ SVI } & \multicolumn{2}{|l|}{$S_{\text {out }}$} & \multirow{2}{*}{$\begin{array}{l}\text { Percentage of } \\
\text { average removal } \\
\text { Eff. Error S }(\%)\end{array}$} \\
\hline & & & Real & Theo. & \\
\hline$\overline{1 / 1}$ & 119 & 130 & 16 & 17.4 & 1.20 \\
\hline $5 / 1$ & 146 & 129 & 15 & 19.4 & 3.01 \\
\hline $9 / 1$ & 133 & 141 & 16 & 18.5 & 1.90 \\
\hline $15 / 1$ & 124 & 152 & 16 & 17.8 & 1.45 \\
\hline $21 / 1$ & 138 & 132 & 16 & 18.9 & 2.20 \\
\hline $26 / 1$ & 132 & 120 & 17 & 18.4 & 1.00 \\
\hline \multicolumn{3}{|c|}{ Average error } & & & 2.15 \\
\hline
\end{tabular}

Table 6: Simulation results for Zenine WWTP in Mar. 2001

\begin{tabular}{|c|c|c|c|c|c|}
\hline \multirow[b]{2}{*}{ Date } & \multirow[b]{2}{*}{$S_{\mathrm{f}}$} & \multirow[b]{2}{*}{ SVI } & \multicolumn{2}{|l|}{$S_{\text {out }}$} & \multirow{2}{*}{$\begin{array}{l}\text { Percentage of } \\
\text { average removal } \\
\text { error S }(\%)\end{array}$} \\
\hline & & & Real & Theo. & \\
\hline $1 / 3$ & 127 & 128 & 20 & 17.72 & 1.80 \\
\hline $5 / 3$ & 160 & 144 & 23 & 18.90 & 2.50 \\
\hline $13 / 3$ & 174 & 164 & 24 & 20.60 & 2.00 \\
\hline $17 / 3$ & 166 & 144 & 22 & 20.20 & 1.10 \\
\hline $22 / 3$ & 110 & 101 & 14 & 16.30 & 2.10 \\
\hline $31 / 3$ & 135 & 122 & 30 & 18.30 & 8.67 \\
\hline \multicolumn{5}{|c|}{ Average error } & 3.03 \\
\hline
\end{tabular}

Table 7: Simulation results for Zenine WWTP in May 2001

\begin{tabular}{|c|c|c|c|c|c|}
\hline \multirow[b]{2}{*}{ Date } & \multirow[b]{2}{*}{$S_{\mathrm{f}}$} & \multirow[b]{2}{*}{ SVI } & \multicolumn{2}{|l|}{$S_{\text {out }}$} & \multirow{2}{*}{$\begin{array}{l}\text { Percentage of } \\
\text { average removal } \\
\text { Eff. error S }(\%)\end{array}$} \\
\hline & & & Real & Theo. & \\
\hline $2 / 5$ & 130 & 91 & 15 & 18.30 & 2.54 \\
\hline $4 / 5$ & 137 & 95 & 20 & 18.80 & 1.00 \\
\hline $6 / 5$ & 111 & 96 & 13 & 16.70 & 3.33 \\
\hline $10 / 5$ & 112 & 111 & 18 & 16.89 & 1.00 \\
\hline $15 / 5$ & 117 & 119 & 18 & 17.30 & 1.50 \\
\hline $20 / 5$ & 141 & 143 & 29 & 19.10 & 7.02 \\
\hline $26 / 5$ & 160 & 119 & 27 & 20.31 & 4.20 \\
\hline $31 / 5$ & 103 & 150 & 11 & 16.10 & 4.95 \\
\hline \multicolumn{5}{|c|}{ Average error } & 3.20 \\
\hline
\end{tabular}

Table 8: Simulation results for Zenine WWTP in July 2001

\begin{tabular}{|c|c|c|c|c|c|}
\hline \multirow[b]{2}{*}{ Date } & \multirow[b]{2}{*}{$\mathrm{S}_{\mathrm{f}}$} & \multirow[b]{2}{*}{ SVI } & \multicolumn{2}{|l|}{$\mathrm{S}_{\text {out }}$} & \multirow{2}{*}{$\begin{array}{l}\text { Percentage of } \\
\text { average removal } \\
\text { Eff. error S (\%) }\end{array}$} \\
\hline & & & Real & Theo. & \\
\hline $1 / 7$ & 147 & 141 & 44 & 18.20 & 17.55 \\
\hline $4 / 7$ & 95 & 133 & 11 & 14.80 & 4.00 \\
\hline $7 / 7$ & 121 & 116 & 5 & 16.50 & 9.50 \\
\hline $10 / 7$ & 101 & 106 & 10 & 14.50 & 4.45 \\
\hline $13 / 7$ & 93 & 91 & 35 & 14.90 & 21.60 \\
\hline $19 / 7$ & 127 & 142 & 20 & 16.94 & 2.90 \\
\hline $25 / 7$ & 109 & 175 & 16 & 15.60 & 0.36 \\
\hline $31 / 7$ & 140 & 231 & 8 & 17.80 & 7.00 \\
\hline \multicolumn{5}{|c|}{ Average error } & 8.42 \\
\hline
\end{tabular}

This is performed by studying the effect of operating parameters: influent flow rate, recycle ratio, wastage ratio, power input and influent composition of substrate and biomass on removal efficiency of the substrate (BOD) and ammonia.

Suwa et $a l .^{[11]}$ studied the effect of the operational performance on percentage nitrogen removal efficiency by a single-stage, single-sludge activated sludge process.
Table 9: Simulation results for Zenine WWTP in Sept. 2001

\begin{tabular}{|c|c|c|c|c|c|}
\hline \multirow[b]{2}{*}{ Date } & \multirow[b]{2}{*}{$\mathrm{S}_{\mathrm{f}}$} & \multirow[b]{2}{*}{ SVI } & \multicolumn{2}{|l|}{$\mathrm{S}_{\text {out }}$} & \multirow{2}{*}{$\begin{array}{l}\text { Percentage of } \\
\text { average removal } \\
\text { Eff. error S }(\%)\end{array}$} \\
\hline & & & Real & Theo. & \\
\hline $1 / 9$ & 131 & 98 & 20 & 18.10 & 1.53 \\
\hline $5 / 9$ & 109 & 122 & 19 & 16.30 & 2.50 \\
\hline $8 / 9$ & 110 & 133 & 14 & 16.64 & 2.40 \\
\hline $15 / 9$ & 119 & 138 & 11 & 17.20 & 5.21 \\
\hline $22 / 9$ & 99 & 193 & 9 & 15.50 & 5.57 \\
\hline $25 / 9$ & 102 & 217 & 10 & 15.50 & 5.24 \\
\hline $30 / 9$ & 133 & 203 & 10 & 18.20 & 6.20 \\
\hline \multicolumn{5}{|c|}{ Average error } & 4.05 \\
\hline
\end{tabular}

Table 10: Simulation results for Zenine WWTP in Dec. 2001

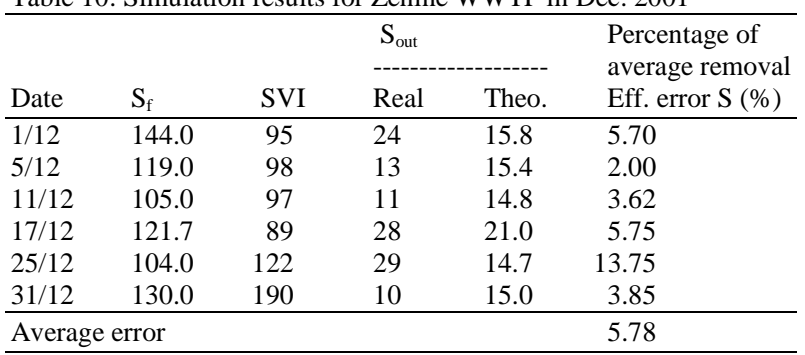

They found that more than $97 \%$ of the organic carbon was removed and only small concentrations of the $\mathrm{NH}_{4}$ $\mathrm{N}_{2}$ were found in the effluent.

The data shown in Table 1 and the kinetic and stoichiometric coefficients shown in Table 2 will be considered. When one parameter is concerned with under study, the others are maintained as constants. Sludge age, $\theta_{c}$, is defined as the ratio of biomass in the reactor to the net rate of biomass. It is often called solids retention time in the reacting system. It has a principal effect on the performance and capabilities of an activated sludge system. It is important in activated sludge systems because it is an operational parameter that can be physically controlled to maintain treatment performance. David et al. ${ }^{[12]}$ landmark study linked the sludge age to the treatment efficiency thereby providing means of maintaining treatment performance by manipulating physical attributes such as wastage rate.

At steady state conditions, the net rate of biomass generation is equal to the rate at which biomass flows out of the system. If biomass is removed through the recycle line and by losses in the clarifier overflow, the sludge age, as shown in Fig. 1, is given by:

$\theta_{\mathrm{c}}(\mathrm{d})=\frac{\mathrm{VX}}{\mathrm{QWX}_{\mathrm{r}}+\mathrm{Q}_{\mathrm{e}} \mathrm{X}_{\mathrm{e}}}=\frac{\mathrm{V}(\mathrm{R}+\mathrm{W})}{\mathrm{QW}(1+\mathrm{R})}$

where, $\mathrm{X}_{\mathrm{e}}=0.0$.

The sludge age can be controlled either by the sludge wastage rate from the bottom of the clarifier or by the rate of sludge recycle. Through experience, 
operators of conventional activated sludge reactors have found that $\theta_{c}$ should usually lie between 3-14 days in order to produce a biological floc which can be handled easily. For $\theta_{c}$ less than 3 days, the biomass is not dense enough to settle easily, producing "bulking sludge". For $\theta_{c}$ greater than 14 days, the floc particles are too small to settle rapidly and the fraction of living cells in the biomass is low. Good sludge settling properties are essential for an efficient gravity settler operation and a stable activated sludge process. Since the sludge age largely governs how well a floc will settle, a value is chosen based upon experience and the type of sludge generated in the process.

The sludge age can be controlled by the wastage rate from the bottom of the settler or by the rate of sludge recycle. By decreasing the sludge wastage rate, the sludge age is increased. The same result can be obtained when $\mathrm{R}$, the rate of recycle ratio is increased. Perdrieux and Therien ${ }^{[13]}$ and Hashimoto et al. ${ }^{[14]}$ showed that the higher the sludge age the better assimilation of the substrate by the cell and the more the rate of utilization of the stored carbon for energetic requirements.

Effect of recycle ratio: The purpose of the recycle of sludge is to maintain a sufficient concentration of activated sludge and increase the concentration of the biomass in the aeration basin. The addition of a recycle stream also dilutes the concentration of entering substrate and decreases the residence time of fluid elements in the aeration basin. So the required degree of treatment can be obtained in the time interval desired. The return of activated sludge from the clarifier to the inlet of the aeration tank is the essential feature of the process.

The recycle ratio $(\mathrm{R}(\%))$ is defined as the ratio between the recycle flow rate to the aeration tank influent flow rate. Figure 2 shows the effect of changing recycle ratio on the percentage removal efficiency of the substrate and ammonia at certain conditions such as $\mathrm{S}_{\mathrm{f}}, \mathrm{H}_{\mathrm{f}}, \mathrm{C}_{\mathrm{f}}$ and $(\mathrm{P} / \mathrm{V})$. It is noted at these conditions that as $\mathrm{R}$ increases, the removal efficiency of substrate increases from a very small value at very low values of $\mathrm{R}(\%)$ till it reaches $84 \%$ at $\mathrm{R}(\%)=40 \%$, then it reaches $86 \%$ at $\mathrm{R}(\%)=80 \%$. Finally, it becomes almost constant with further increase in $\mathrm{R}(\%)$ where it appears that the substrate removal efficiency is not enhanced by a recycle ratio larger than $80 \%$.

With respect to ammonia, the percentage removal efficiency increases from 33.991 at very small values of recycle ratio and reaches $52 \%$ at $\mathrm{R}(\%)$ equal to $80 \%$ then becomes constant as $\mathrm{R}(\%)$ increases. It is the case here also that appeared that ammonia removal efficiency is not enhanced by a recycle ratio larger than $80 \%$. This can be explained in the first stage where removal efficiency of substrate and ammonia increases continuously when $\mathrm{R}(\%)$ in the range increases (0$80 \%$ ), the rate of biomass production increases. This produced biomass can degrade the organic substrate (BOD) and ammonia efficiently. This explains why the percentage removal efficiency increases till it reaches nearly $80 \%$. However, in the second stage, the percentage removal efficiency becomes constant because aeration is unable to supply the excess biomass by the necessary oxygen. Also, the rate of increasing biomass concentration will be reduced as $\% \mathrm{R}$ increases as shown in Fig. 3. When the operating conditions change, the curves in Fig. 2, will have the same shape but they may be shifted to the right or the left according to the available conditions. Figure 3 shows that the effluent biomass concentration $\left(\mathrm{X}_{\text {out }}\right)$ will always increase as $\mathrm{R}(\%)$ increases due to the biomass resulting from the degradation of the substrate and ammonia.

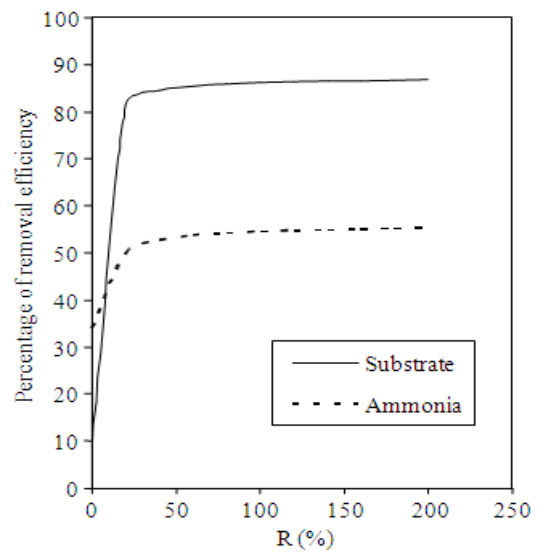

Fig. 2: Effect of recycle ratio on removal efficiency

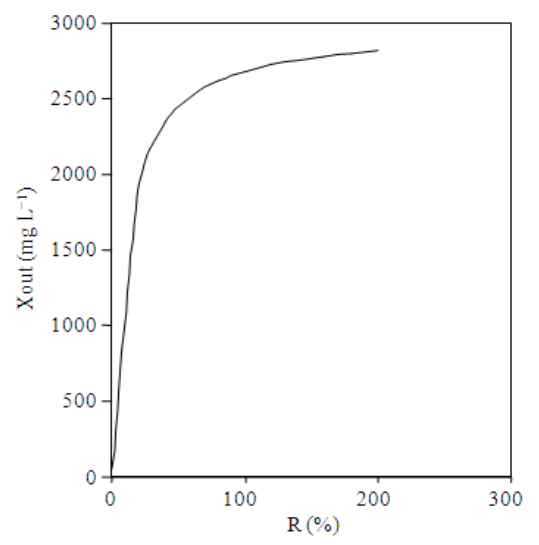

Fig. 3: Effect of recycle ratio on biomass effluent 
Am. J. Environ. Sci., 5 (3): 352-363, 2009

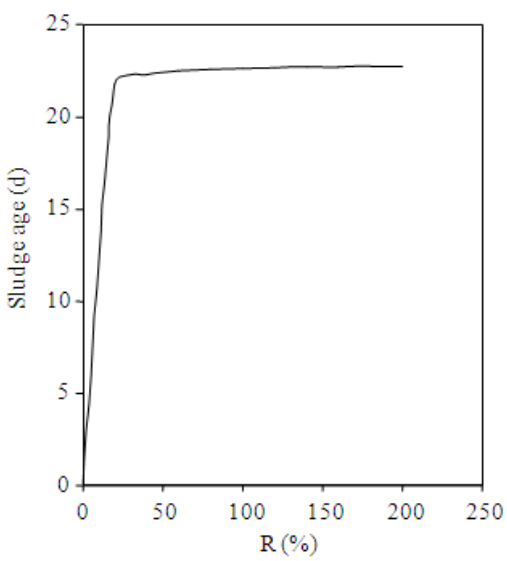

Fig. 4: Effect of recycle ratio on sludge age

Yuichi Suwa et al. ${ }^{[10]}$ showed that the higher the concentration of sludge biomass in an aeration basin, the larger the number of microorganisms and the number of flocs which possess aerobic and anoxic micro-sites inside the flocs. Thus the oxidation and denitrification rate in the aeration basin will be enhanced by higher volumetric BOD loading. Since organic matter is essential for oxidation and denitrification as the electron donor. Tashiro et al. ${ }^{[14]}$ showed that it might be difficult to carry out simultaneous carbon-nitrogen removal when the influent is applied to this process.

Since the sludge age largely governs how well a floc will settle, it is important to study the effect of recycle ratio on sludge age. Figure 4 shows the effect of changing $\mathrm{R}(\%)$ on the sludge age, $\theta_{\mathrm{c}}$, in the aeration tank. It is shown that $\theta_{\mathrm{c}}$ increases continuously as $\mathrm{R}(\%)$ increases. It is noted that an increasing in $\mathrm{R}(\%)$ will increase the biomass concentration and consequently a better assimilation of the substrate by the cell can be obtained and the rate of utilization of the substrate for energetic requirements can be increased.

Hence, the sludge age can be controlled by the sludge recycle from the bottom of the clarifier.

Effect of influent flow rate: It is very important to study the effect of influent flow rate on the \% removal efficiency because it is an external factor and is very difficult to control. Logically, increasing the flow rate will cause high loading on the performance of the plant. Figure 5 shows the effect of increasing the flow rate on the removal efficiency of substrate and ammonia. It is shown that the removal efficiency of substrate decreased from $100 \%$ at very small values of flow rate to $36.5 \%$ at $\mathrm{q}=100,000 \mathrm{~m}^{3} \mathrm{day}^{-1}$. The same pattern is repeated for ammonia but the removal efficiency of ammonia is less than that of the substrate.

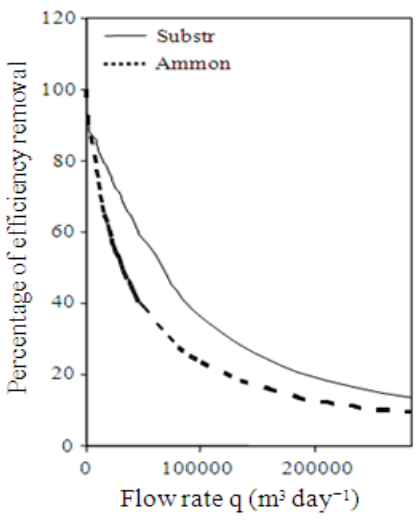

Fig. 5: Effect of flow on removal efficiency

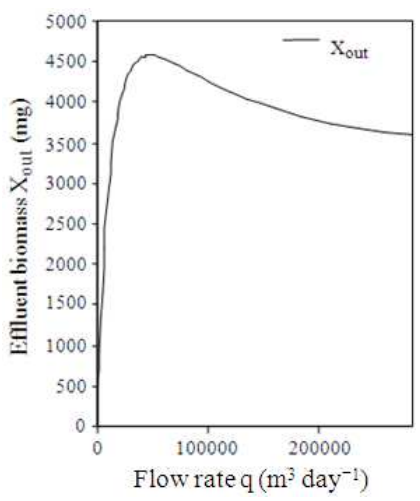

Fig. 6: Effect of flow on effluent biomass

Figure 6 shows that $X_{\text {out }}$ increases from $25 \mathrm{mg} \mathrm{L}^{-1}$ till the highest value of $4577 \mathrm{mg} \mathrm{L}^{-1}$ at $50,000 \mathrm{~m}^{3}$ day $^{-1}$ then decreases as the flow rate increases till it becomes constant. The highest value of $X_{\text {out }}$ (the optimum value) corresponds to critical flow rate. The microorganisms after this critical rate are washed out of the reactor faster than they are generated by the reaction under washout conditions; the concentration of biomass in the reactor decreases and the conversion of substrate decreases.

In fact, optimizing the different flow rates in the plant is an important factor in wastewater plant operation. An industrial plant should operate in a range of flow rate close to the critical to fulfill the highest effluent biomass such as Helwan WWTP which has flow rate of $43,750 \mathrm{~m}^{3}$ day $^{-1}$. Maintaining a high concentration of biomass is a tempting strategy to improve plant performance, since a large biomass can degrade more organic material. However other forms of microorganisms may adapt to the high concentration of biomass which in turn makes the activated sludge process less efficient. These results agree with 
Am. J. Environ. Sci., 5 (3): 352-363, 2009

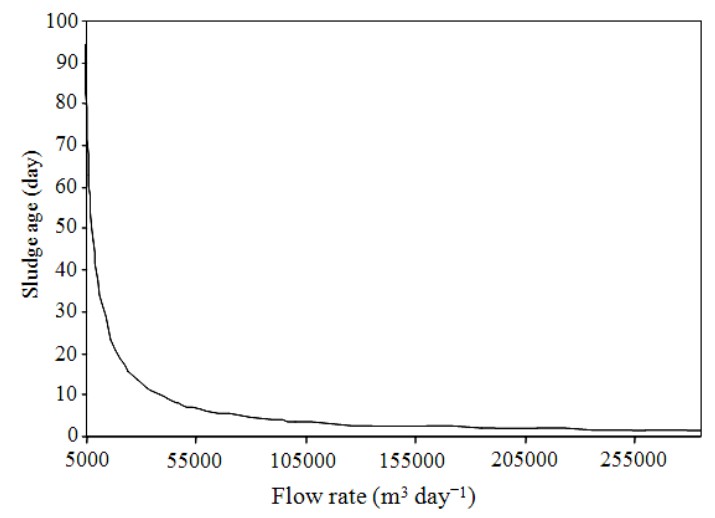

Fig. 7: Effect of flow rate on sludge age

those of Muller et al. ${ }^{[16]}$ who showed that a very low biomass production could be achieved when a very high influent flow rate is applied.

Figure 7 shows that increasing the flow rate will decrease the sludge age in the reactor, hence, the removal efficiency of the aeration basin decreases. The microorganisms will not have enough time to oxidize the substrates and ammonia. It is required to control the influent flow rate to maintain a high conversion. The sludge age can be calculated at the critical flow rate according to Eq. 14. It equals 8.6 days; it is a good value for the sludge age that gives sufficient time to perform different biodegradations.

Effect of influent substrate concentration: The influent composition is important for the design and control of a WWTP. The concentration of influent substrate concentration determines the performance of the plant. Benefield and $\mathrm{Molz}^{[17]}$ showed that although substrate treatment would not likely be affected until a very low DO was reached, a distinction between excess and low DO was made since nitrification can be limiting at DO concentrations less than $2 \mathrm{mg} \mathrm{L}^{-1}$.

In Fig. 8, the behavior of percentage removal efficiency can be classified into two stages. In the first, the conversion of substrate increases with increasing $S_{f}$ from $77.7 \%$ at small values of $S_{\mathrm{f}}$ to reach $96.5 \%$ at $\mathrm{S}_{\mathrm{f}}=700 \mathrm{mg} \mathrm{L}^{-1}$. Then it becomes constant as $\mathrm{S}_{\mathrm{f}}$ increases. It means that the output substrate concentration remains constant, but in the second stage, the effluent substrate concentration remains constant and it does not depend upon the entering substrate concentration. It appeared that the removal efficiency was not enhanced by $\mathrm{S}_{\mathrm{f}}$ larger than $700 \mathrm{mg} \mathrm{L}^{-1}$.

This response represents an inherent "self control" by the reactor since changes in feed concentration do not affect the output substrate concentration ${ }^{[13]}$.

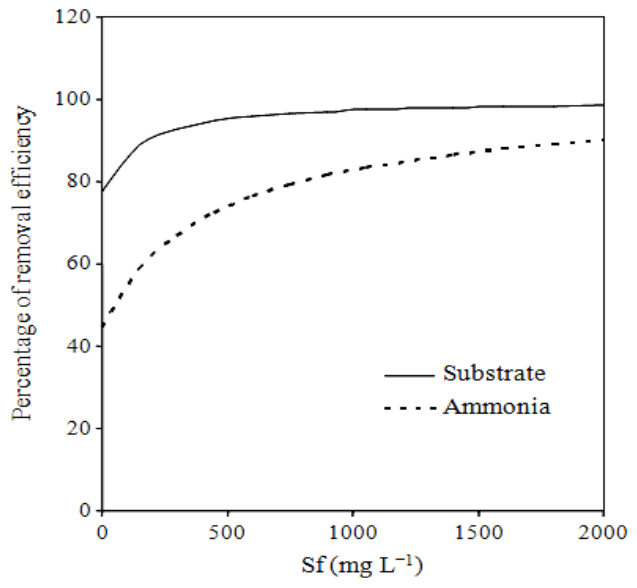

Fig. 8: Effect of feed concentration on percentage of removal efficiency

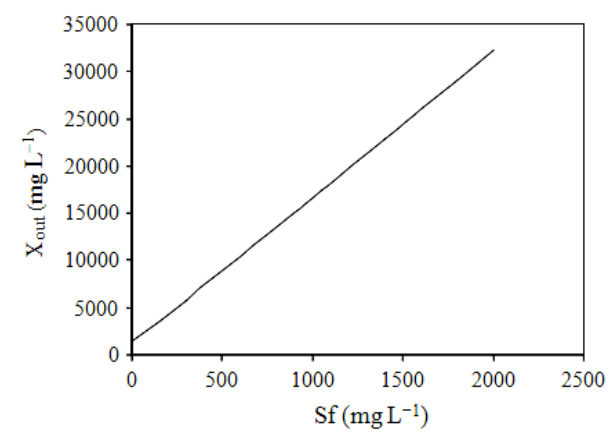

Fig. 9: Effect of Feed substrate concentrations on effluent biomass $\left(\mathrm{X}_{\text {out }}\right)$

This can be understood by Fig. 9 where the effluent biomass (biological solids) concentration is increasing linearly as $S_{\mathrm{f}}$ increases sufficiently to handle the higher loading of the substrate. The percentage removal efficiency of ammonia increases from $44.3 \%$ at very small value of $S_{\mathrm{f}}$ then it increases continuously till it reaches $86.6 \%$ at $S_{\mathrm{f}}=1409 \mathrm{mg} \mathrm{L}^{-1}$.

\section{CONCLUSION}

A mathematical process model was developed for the aeration tank of the activated sludge process for four main components in addition to biomass. Identification of kinetic and stoichiometric parameters was undertaken in order to obtain suitable values of parameters (as shown in Table 2) to prepare the model for the simulation purpose and to obtain results compatible with existing activated sludge plants. It was found that some parameter values such as half saturation coefficients were found out of the range of 
the activated sludge model number $1 \mathrm{ASM} 1^{[4]}$ due to considering the mass transfer limitations in the floc model. Some other parameter values were assumed like the ammonia stripping factor and the other parameters like saturated concentration of oxygen were taken from ranges given in the literature.

In this study two Egyptian WWTPs were used: Helwan WWTP and Zenine WWTP. The two plants are different in some conditions such as aeration tank volume, flow rates and the aeration technique. Helwan WWTP uses the surface aeration with mechanical agitation technique but Zenine WWTP uses the diffused air technique.

Helwan WWTP data was used through the simulation of the response of different components of substrate (BOD) and ammonia. Zenine WWTP was used for testing and validation of the process model through the prediction of the substrate only. The average relative errors of the removal efficiency between the real measurements in the plant and the theoretical results of the process model were calculated. The average error of the removal efficiency in Helwan WWTP reached $3.3 \%$ for the substrate and $12.5 \%$ for the ammonia. However, in Zenine WWTP it reached $4.6 \%$ for the substrate. These results emphasize the model validation and the kinetic parameter accuracy.

A parametric sensitivity of the activated sludge process also was performed. The effects of recycle ratio, flow rate, influent substrate concentrations on the removal efficiency of the aeration tank were studied. It has been found that the removal efficiency of substrate and ammonia was increased by increasing the recycle ratio, influent substrate concentrations and also increased by decreasing the influent flow rates. It has been found that the sludge age increased by increasing the recycle ratio and decreased by decreasing the influent flow rates.

The highest value of $X_{\text {out }}$ was determined as well as the corresponding flow (the critical flow rate). The microorganisms after the critical flow rate are washed out of the reactor faster than they are generated by the reaction under washout conditions; so the concentration of biomass in the reactor decreases and the was calculated at the critical flow rate according to 8.6 days; this is a good value for the sludge age and gives sufficient time to perform different biodegradations.

\section{REFERENCE}

1. Mustafa, I.H., G. Ibrahim, A. Elkamel and A.H. Elahwany, 2009, Modeling of activated sludge floc characteristics. Am. J. Environ. Sci., 5: 69-79.

http://www.scipub.org/fulltext/ajes/ajes5169-79.pdf
2. Wilén, B.M., D. Lumley, A. Mattsson and T. Mino, 2008. Relationship between floc composition and flocculation and settling properties studied at a full scale activated sludge plant. Water Res., 42: 44044418. DOI: 10.1016/J.WATRES.2008.07.033

3. Yuansong, W., Y. Wang, X. Guo and J. Liu, 2009. Sludge reduction potential of the activated sludge process by integrating an oligochaete reactor. J. Hazard. Mater., 163: 87-91. DOI: 10.1016/ J.JHAZMAT.2008.06.065

4. Henze, M., L. Grady, W. Gujer, G.V.R. Marais and T. Matsou, 1987. A general model for single sludge wastewater treatment systems. Water Res., 21: 505-515. DOI: 10.1016/0043-1354(87)90058-3

5. Shieh, W.K. and T.L. Mulcahy, 1986. Experimental determination of intrinsic kinetic coefficients for biological wastewater treatment systems. Water Sci. Technol., 18: 1-10.

6. Alison, S.H. and H.P. Dare, 1993. Measuring maximum specific growth rate and half saturation coefficient for activated sludge systems using a freeze concentration technique. Water Res., 27: 1793-1795.

http://cat.inist.fr/?aModele=afficheN\&cpsidt=3754029

7. Metcalf and Eddy Inc., 1990. Wastewater Engineering: Treatment Disposal Reuse. 10th Edn., Mc Graw-Hill Inc., NewYork, USA., pp: 100-180.

8. Tyagi, R.D., Y.G. Du and Bhamidimarri, 1996. Dynamic behavior of the activated sludge under shock loading: Application of the floc model. Water Res., 30: 1605-616. DOI: 10.1016/00431354(96)00045-0

9. Zhang, M., J.H. Tay, Qian and X.S. Gu, 1998. Coke plant wastewater treatment by fixed biofilm system for COD and NH3-N removal. Water Res., 32: 519-527. DOI: 10.1016/S0043-1354(97)00231-5

10. Lessard, P. and M.B. Beck, 1993. Dynamic modeling of the activated sludge process: A case study. Water Res., 27: 963-978. DOI: 10.1016/0043-1354(93)90060-U

11. Suwa, Y., T. Suzuki, H.T.T. Yamagishi and Y. Urushigawa, 1992. Single-stage single-sludge nitrogen removal by an activated sludge process with cross-flow filtration. Water Res., 26: 1149-1157. DOI: 10.1016/0043-1354(92)90174-3

12. David, R., P. Saucez, J.L. Vasel and A.V. Wouwer, 2009. Modeling and numerical simulation of secondary settlers: A method of lines strategy. Water Res., 43: 319-330. DOI: 10.1016/J.WATRES.2008.10.037

13. Perdrieux, S. and N. Therien, 1980. Modeling the dynamics of the activated sludge wastewater treatment process in terms of the carbon variable. Water Res., 14: 1333-1344. DOI: 10.1016/0043354(80)90194-3 
14. Hashimoto, T., K. Onda, Y. Nakamura, K. Tada, A. Miya and T. Murakayymi, 2007. Comparison of natural estrogen removal efficiency in the conventional activated sludge process and the oxidation ditch process. Water Res., 41: 2117-2126. DOI: 10.1016/J.WATRES.2007.02.029

15. Tashiro, T., Y. Suwa, T. Yamagishi and M. Hirai 1990. Ammonium oxidation by an activated sludge process with cross-flow filtration. Hakkokogaku, 68: 31-34. (In Japanese).
16. Muller, E.B., A.H. Stouthamer, H.W. Van Verseveld and D.H. Eikelboom, 1995. Aerobic domestic wastewater treatment in a pilot plant with complete sludge retention by cross-flow filtration. Water Res., 29: 1179-1189. DOI: 10.1016/00431354(94)00267-B

17. Benefield, L. and F. Molz, 1984. A model for the activated sludge process which considers wastewater characteristics, floc behavior andmicrobial population. Biotechnol. Bioeng., 26: 352-361. DOI: 10.1002/bit.260260410. 